\title{
POESIAS SUSSURRANTES
}

Mércia Paulino é mestranda em Teoria da Literatura na UFPE- Recife, do Programa de Pós-Graduação em Letras. E-mail: paulino.mercia@gmail.com

\section{Tú}

Mi amor, amor mío,

Tú, que alumbras mi ser con tu sonrisa,

Tú, que arrullas mi vida con tu voz,

Tú, que enseñas mi alma con tu mirada,

Tú, que reanimas mi espíritu con tu aliento,

A tú, solamente, dedico mis horas,

A tú, singularmente, ofrezco mis días,

A tú, únicamente, entrego mi tiempo,

A tú, exclusivamente, prometo mi amor.

\section{Natureza natural}

Quando estou ao seu lado, percebo a natureza natural em que vivo

e quero

me sujar na areia,

me banhar no mar,

me molhar na chuva,

me iluminar na luz do luar.

mas, ainda quero

me inspirar com o teu olhar,

me refrescar com teus beijos,

me adornar com teu sorriso e

me encharcar com os teus anseios. 


\section{Questões}

Perguntas sem respostas

não quer responder

não quer escutar

somente perguntar

apenas por indagar

pra interrogar

pra procurar

pra inquirir

pra ouvir

a sua própria voz que ecoa dentro e fora de si. 